\title{
The role of the Tatar educational elite in the formation of national socio-political thought at the turn of the XIX-XX centuries (modern research aspects)
}

\section{El papel de la élite educativa tártara en la formación del pensamiento sociopolítico nacional a finales del siglo XIX-XX (aspectos de la investigación moderna)}

\begin{abstract}
Albina R. Akhmetova
Candidate of Historical Sciences, Associate Professor, Department of World Cultural Heritage, Division of the Higher School of Historical Sciences and World Cultural Heritage, Institute of International Relations, Kazan Federal University. ORCID: 0000-0002-0270-615X

\section{Lilia Rifkhatovna Galimzyanova}

Candidate of Historical Sciences, Associate Professor, Department of World Cultural Heritage, Division of the Higher School of Historical Sciences and World Cultural Heritage, Institute of International Relations, Kazan Federal University.

ORCID: 0000-0003-4359-4657

\section{Lyudmila Sergeevna Timofeeva}

Candidate of Historical Sciences, Associate Professor, Department of World Cultural Heritage, Division of the Higher School of Historical Sciences and World Cultural Heritage, Institute of International Relations, Kazan Federal University.
\end{abstract}

ORCID: 0000-0002-4637-8901

* Correspondence

E-mail: albina-ahmetova303@mail.ru.
Citation:

A.R. Akhmetova, L.R. Galimzyanova, L.S. Timofeeva. (2021). The role of the Tatar educational elite in the formation of national socio-political thought at the turn of the XIX-XX centuries (modern research aspects). $\begin{array}{llll}\text { Propósitos y } \quad \text { Representaciones, } & \text { 9(SPE2), } & \text { e1101. }\end{array}$ http://dx.doi.org/10.20511/pyr2021.v9nSPE2.1101 


\begin{abstract}
At the end of the 20th century, changes took place in the world that forced politicians and scientists to rethink many seemingly established postulates about the laws of social life and about the ways of development of human civilization. The modern development of the social movement among the Tatars of Russia, and especially the national processes in Tatarstan largely repeat the trends in the development of the nation in the pre-Soviet period. The main role in the social movement of nations is played by the activities of the elite aimed at creating political, educational and cultural institutions. The turning point in the history of the Tatar people should be considered the end of the 19th - the beginning of the 20th century. The Tatar ideology was created during the period of rapid development of bourgeois socio-economic relations (especially noticeable among the Tatars of the Volga-Ural region) and the rise of national culture. However, until recently, the sources and works of authors of different times have not been fully studied, although they contain data on the processes of formation of the Tatar social factor and the Tatar nation itself in the context of the development of the Russian community.
\end{abstract}

Keywords: Enlightenment, social movement, Jadidism, national culture, education.

\title{
Resumen
}

A finales del siglo XX, se produjeron cambios en el mundo que obligaron a políticos y científicos a repensar muchos postulados aparentemente establecidos sobre las leyes de la vida social y sobre las formas de desarrollo de la civilización humana. El desarrollo moderno del movimiento social entre los tártaros de Rusia, y especialmente los procesos nacionales en Tatarstán, repiten en gran medida las tendencias en el desarrollo de la nación en el período pre-soviético. El papel principal en el movimiento social de las naciones lo desempeñan las actividades de la élite destinadas a crear instituciones políticas, educativas y culturales. El punto de inflexión en la historia del pueblo tártaro debe considerarse el final del siglo XIX, el comienzo del siglo XX. La ideología tártara se creó durante el período de rápido desarrollo de las relaciones socioeconómicas burguesas (especialmente notable entre los tártaros de la región del Volga-Ural) y el surgimiento de la cultura nacional. Sin embargo, hasta hace poco, las fuentes y obras de autores de diferentes épocas no han sido completamente estudiadas, aunque contienen datos sobre los procesos de formación del factor social tártaro y la propia nación tártara en el contexto del desarrollo de la comunidad rusa.

Palabras clave: Ilustración, movimiento social, jadidismo, cultura nacional, educación.

\section{Introduction}

The beginning of the Russian historiography of the Tatar social movement was laid by the works of missionaries who analysed the development of Islam, European education and the Tatars social movement. The founder of this tradition at the end of the 19th century was N.I. Ilminsky, who sought to prevent changes within the Tatar Muslim society. In the 1910s, Russian scientists were coming to an understanding of the need to study the social movement of non-Russian ethnic groups in the Russian Empire. In 1910, the ethnographer L. Sternberg in the chapter of the book "Forms of the National Movement in Modern Conditions" "Members of national minorities" gave an initial description of the Muslim movement in Russia and emphasized the leading role of the Tatars in the Muslim political movement and educational reform (Sternberg, 1910).

Also, one of the prerequisites for the emergence of national socio-political thought was the emergence of the educational movement from the middle of the 19th century. Let's consider it in more detail.

The first attempts to comprehend the heritage of the Tatar enlighteners belong to such Tatar scientists and cultural figures of the late 19th - early 20th centuries as Sh.Mardzhani, K. Nasyri, R. Fakhretdin. The history of individual educational institutions, the spread of education in the region received the greatest coverage in historical works during that period, but the authors, as 
a rule, did not ask questions about the historical essence of Tatar enlightenment, the factors of its evolution, and about the periodization of this phenomenon.

During this period, new political forces entered the public arena; a qualitative change in public consciousness took place on the basis of religious reform, the educational movement and Jadidist ideas, which became the theoretical basis of the national movement.

In the Soviet period, there was a need to assess the history of the development of the nation's social movement, its leaders and institutions. In the 1920s, we see three directions in Tatar historiography.

The first, the proper Jadidist, concentrated on the study of the development of the nation through the history of enlightenment and literature. The "History of Tatar Literature" created by Gaziz Gubaidullin and Ali Rakhim played a fundamental role here. It analysed the history of Tatar literature from runic monuments and Orkhon-Yenisei inscriptions to the middle of the 19th century. A feature of the authors' approach was the study of literature through the prism of general cultural development. When analysing the origins of the national political movement, $G$. Gubaidullin focused on its unity. Jamal Validi created "Essays on the History of Education and Literature of the Tatars", which is to this day the most complete outline of the development of social thought and spiritual culture of the nation (Validov, 1923). The second direction advocated the autonomous development of the nation along the path of world civilization. Its most prominent representatives were Gasim Mansurov and Iskhak Kazakov. They developed the thesis of the unity of the national movement in matters of culture and education. The book by G. Mansurov "Tatar provocateurs" still remains a unique encyclopaedia on the history of the political movement of the Tatars at the beginning of the 20th century. The founder of the third direction was Galimjan Ibragimov. This direction specialized in criticizing the previous national movement and personally M. Sultan-Galiev. The primacy of linguistic and cultural principles was characteristic of national identity for G. Ibragimov. His work "Tatars in the 1905 Revolution" laid the foundations for the entire tradition of analysing the formation of the Tatar social movement. The author emphasized in it the leading role of the bourgeoisie in the creation of the nation and the counter-revolutionary role of the liberal and moderate socialist movement among the Tatars. G. Ibragimov created a picture of the national Bolshevik movement. The concept of the unity of the national movement was rejected in the works of this school. The book by A. Arsharuni and H. Gabidullin "Essays on PanIslamism and Pan-Turkism in Russia" emphasized the relationship between all forms of national movement (including the activities of supporters of M. Sultan-Galiev) with the Russian and international anti-Soviet movement. Because of the repressions against all forms of the Tatar social movement in 1929-1937, there has ceased the tradition of Tatar national historiography, the origins of all three directions of which were in the Jadid movement. In the 1960s - 1980s, questions were raised about the specifics of the development of social and political thought inherent in the Tatar ethnos, about the origins of Tatar enlightenment; the historical place and role of its individual representatives in the development of national spiritual culture were analysed.

In the 1990-2000s, the problems of the topic considered by us have been updated; the research base has been expanded. The authors mobilized new concepts and theories, which have been developed in world historical, sociological and political thought. Civilizational and sociocultural approaches and ethnomethodology positions are clearly traced in the works by B.S. Erasov, G.V. Miloslavsky, V.I. Moryakov, S.Kh. Alishev, Ya.G. Abdullin, R.U. Amirkhanov, S.M. Mikhailova, E.A. Vishlenkova, R. F. Mukhametdinov, D. M. Iskhakov, S. M. Iskhakov, R. R. Fakhrutdinov, R. M. Mukhametshin, A. Yu. Khabutdinov, A. N. Yuzeev, L.M. Aynutdinova, D.M. Usmanova, R.A. Tsiunchuk, L.A. Yamaeva.

The scientific circulation involves the works of foreign authors and emigrants from the USSR, who dealt with the problems of the history of Tatar social thought and Tatar enlightenment A. Avtorkhanov, T. Davletshin, A. Bennigsen, S. Duduanion, A. Rohrlich, F. Zhorzhon, etc. 


\section{Results and Discussion}

The result of the actions and initiatives of the Tatar reformers and educators of the late 18th - 19th centuries was the restructuring of the entire Tatar society, which led to a gradual change in the education system, the creation of a modern Tatar literary language and periodicals in the Tatar language. These reforms led to the emergence of a qualitatively new group of the Muslim elite, namely the national secular intelligentsia. The Muslim newspaper "Musulmanskaya gazeta" wrote about the significant role of the intelligentsia. "No one will deny that the intelligentsia, which devotes itself to serving the motherland and the benefit of its nation, plays a huge role in the progress of this or that state, this or that nationality. ... In order to awaken the self-awareness of a particular people, to explain its position to it, you need to speak with it in its native and understandable language. Thus, knowledge of the language, knowledge of literature, in a word, knowledge of the psyche of the people, which the intelligentsia should serve, are an essential necessity and important conditions of this case" (Musulmanskaya gazeta, 1913). The end of the 19th - the beginning of the 20th century should be considered the turning point in the history of the Tatar people. This period was marked by a powerful rise of the national movement among the Tatars along the path of progress and the desire to become active creators of their history.

The revolution of 1905-1907 intensified the social and political movement. One of the directions of the social movement at the beginning of the twentieth century was the movement of shakirds (students of madrasahs). In 1895-1900, a secret literary and political circle "Tarraki" was formed in the Kazan Tatar teacher's school. It was headed by G. Iskhaki, S. Maksudi, G. Teregulov, H. Yamashev. The circle studied Persian, Russian, Turkish literature, promoted the ideas of the national liberation movement among the Shakirs, and published the illegal newspaper "Tarraki" (Progress) (Tatar Encyclopedic Dictionary, 1999).

In 1901 - 1904, in Kazan there was a secret organization of Tatar youth "Shakirdlik". The program of this organization had an anti-government orientation. They published the handwritten newspaper "Tarakki". Subsequently, this organization was transformed into the political organization "Horriyat".

In 1901-1905, the Shakird organization "Ittikhad" was founded in the madrasah "Mukhammadiya" headed by F. Amirkhan and G.-R. Ibragimov. They proposed reforming the teaching system in madrasahs. They published an illegal newspaper "Al-Magarif" (Tatar Encyclopedic Dictionary, 1999). The "Secret Literary Circle" was formed in 1902 by the shakirds of the "Mukhammadiya" madrasah. The leaders were F. Amirkhan, I. Amirkhan; the circle organized literary evenings, published the illegal newspaper "Tilgen" ("Hawk"). It has disbanded in 1905.

Another illegal political organization "Horriyat" was formed in 1904. Its active members were G. Iskhaki, F. Tuktarov. The organization conducted anti-government and anti-war agitation, and called for evasion from military service. It published the newspaper "Horriyat" and has broken up at the end of 1905.

Many members of these circles took part in the "Al-Islah" ("Reform") movement, an illegal political organization that intensified its activities on the eve of the first Russian revolution in 1904 in Kazan. One should name Y. Akchura, G. Iskhaki, and G.-R. Ibragimov among the most gang figures of the al-Islah movement. As radical political slogans embraced more and more broad strata of the population, this movement was transformed from a purely Jadidist one envisaged, above all, a reform of the educational system, into a politicized revolutionary-democratic movement. Branches of this movement were in the cities of Kasimov, Orenburg, Troitsk, Ufa, Chistopol. Two illegal All-Russian congresses of Tatar shakirds were convened on the initiative of "al-Islah". This movement ceased to function in the second half of 1907 (Nafigov, 1964).

A committee for press affairs was established in Kazan due to the fact that the members of the Shakird movement published illegal literature. The viewing of all publications was entrusted to 
persons who know the oriental languages: N.I. Ashmarin and N.F. Katanov (National Archives of the Republic of Tatarstan, Fund 420, Inventory 1. File 50).

Thus, the Shakird movement pursued the goal of reforming the education system in madrasahs, democratizing and Europeanizing school education, promoting the ideas of the national liberation movement among the Tatars. Participants of the Shakird movement were engaged in propaganda work among Tatar student youth, published illegal handwritten newspapers and magazines, organized literary evenings, concerts of Tatar music, staged plays and performances. Gradually, some of them moved from educational to political activities. All these were new forms of the social and political life of the Tatar intelligentsia and students.

The revolution of 1905-1907 was a kind of catalyst for the formation of political parties. Monarchist, liberal and national parties, blocs and unions appear on the political foreground in addition to the already existing parties of the revolutionary-democratic direction. It was during this period that the first political groups with a more or less pronounced party orientation appeared among the Tatars (Aynutdinova, 2003). The Tatar social revolutionaries united in the "tanchilar" group, and the Tatar social democrats in the "uralchilar" group. These names are modified versions of the names of two newspapers that were the print media of these groups: "Tang Yulduzy" ("Morning Star") and "Ural". The most active figures were G. Iskhaki, F. Tuktarov, Sh. Mukhamedyarov, H. Yamashev, and G. Teregulov. "Tanchilar" and "uralchilar" were practically the only national political groups that formed among the Muslim peoples of the Russian Empire. They belonged to parties with a socialist orientation, had a poorly developed program and a narrow circle of adherents. Their activities were short-lived, and their influence on the Tatar public remained limited. Both groups left the public arena during 1907 (Usmanova, 2005).

All-Russian Muslim congresses of 1905-1906 played a key role in the formation of the Muslim political movement. At the congresses, the national, socio-political and religious problems of the Muslim peoples of Russia, the implementation of the ideas of independent management of the Muslim peoples' affairs, the solution of education problems, the creation of their own political organization defending the interests of the Muslim peoples of Russia in the bodies of representative power were raised. The very fact of their holding became possible only in the conditions of liberalization of the internal political course in the Russian Empire. All-Russian congresses were preceded by regional meetings (Tsiunchuk, 2004).

Two major meetings were held at the beginning of 1905. The first took place on January 23 in the house of a merchant Khusainov under the leadership of G.-R. Ibragimov. The meeting decided to start a petition campaign in order to clarify the needs of Muslims. On January 29, a second meeting took place, which adopted a detailed petition for submission to the tsar. It focused on the elimination of all national, religious and class restrictions, the equalization of Muslims in rights with other nationalities of the empire (Usmanova, 2005).

Legal forms of organization developed by representatives of the Muslim population of the Russian Empire became possible only after the promulgation of the "Manifesto of October 17", which proclaimed freedom of assembly among other democratic freedoms. However, in terms of the composition of the participants, the content of the problems and discussions raised, as well as the nature of the decisions taken, these congresses were a specific phenomenon inherent only in Muslim societies. The first two of the four pre-revolutionary Muslim congresses took place even before the start of the work of the Russian parliament and were held in semi-legal conditions (Usmanova, 2005).

The 1st All-Russian Muslim Congress was held in August 1905. G.-R. Ibragimov and I. Gasprinsky were the initiators of its convocation and its ideologists. The following issues were discussed at the congress: measures and means to improve the education and culture of Muslims; developing positions in relation to missionary policy; on the representation of Muslims in the State Duma; drawing up a memorandum to the sovereign on the legal, spiritual and economic needs of Muslims. The representatives of the congress spoke in favour of the political, civil and religious 
equality of all the peoples of Russia; pointed out the necessity of uniting Russian Muslims on the basis of socio-political and cultural needs; expressed their readiness to launch broad educational work among Muslims. Already at this congress, a split of the Muslim political movement into moderate and more radical parts became apparent. Participants of the Ist All-Russian Muslim Congress decided to create a socio-political Muslim union "Ittifak al-muslimin" (National Archives of the Republic of Tatarstan, Fund 1370).

The opening of the II All-Russian Muslim Congress was scheduled for January 1906 in St. Petersburg. The congress was supposed to consider the following issues:

- Discussion of various petitions on the organization of religious and spiritual administration expressed by Muslims of various localities of Russia, and their earlier petitions for the purpose of uniting and summarizing them;

- Explanations of the highest manifesto of October 17, 1905 in relation to the spiritual, political and economic life of Muslims;

- Clarification of the attitude of Muslims to the State Duma and discussion of the announced programs of various political parties (Usmanova, 2005).

Since from December 19, 1905, public and private assemblies of a political and economic nature were prohibited in St. Petersburg, the Moscow authorities did not allow the II All-Russian Muslim Congress to be conducted. From January 13 to January 22, 1906, private meetings were held, which were recognized by the Muslims as the second congress (National Archives of the Republic of Tatarstan, Fund 199, Inventory 1, file 906). The participants in the meetings decided to act in solidarity with the cadets and seek Muslim representation in the Duma (Usmanova, 2005). One of its most important decisions was the adoption of the charter of Ittifak al-muslimin.

The III All-Russian Muslim Congress was held from 16 to 21 August, 1906 (National Archives of the Republic of Tatarstan, Fund 186, Inventory 1, file 10). Its work was covered by the leading metropolitan publications "Rech", "Oko", "Strana", "Tovarishch", "Russkie vedomosti", "Russkoe slovo", "Novy put'". The participants of the congress were A.M. Topchibashev, I. Gasprinsky, G.-R. Ibragimov, S.-G. Alkin, G. Barudi, Y. Akchura and others. The agenda of the congress included the following issues: the transformation of Ittifak al-muslimin into a political party, the introduction of the electoral principle, the fight against missionary propaganda, the reorganization of the Muslim clergy, the waqfs, and the reform of the national education system. The congress delegates spoke in favour of the early convocation of the State Duma and against the consideration of the Muslim question by government agencies before the start of the work of the Russian parliament (Tatar Encyclopaedia Vol.1. - Kazan, 2002).

At the III All-Russian Muslim Congress, the Muslim national liberation movement split into three streams: conservative, liberal and left wing. The delegates adopted the final version of the program and elected the Ittifaq al-muslimine Central Committee. Thus, the socio-political union was transformed into a political party at the III Muslim Congress. The main initiator of the process on the formation of the Muslim party was Y. Akchura. Many members of the newly formed Ittifak al-Muslimin party were, in parallel, members of the Constitutional Democratic Party. They are Y. Akchura, S. Maksudi, S.-G Alkin. Many points of the "Ittifak al-muslimin" program coincided with the program of the Constitutional Democratic Party. The program involved the establishment of democratic freedoms, the creation of a constitutional-democratic monarchy in Russia, the resolution on the agrarian question, the establishment of national and religious equality, the return of the property of mosques and madrassas to Muslim communities, the development of national languages, culture and school affairs. The leading role in the central committee of "Ittifak al-muslimin" was played by the Kazan Tatars: Y. Akchura, Kh. and S. Maksudi, S.-G. Alkin, G. Barudi, G.-R. Ibragimov (Tatar Encyclopaedia Vol.1. - Kazan, 2002). A resolution was adopted on the following main issues:

- The earliest convocation of the 2nd State Duma and the actual implementation of the freedoms proclaimed by the Manifesto of October 17; 
- Reforming the entire system of public education, namely: introducing compulsory primary education for boys and girls from the age of eight; education in all Muslim institutions in their native language according to a single program; compulsory studying in the Turkish language in secondary schools, and, if possible, in primary schools. It was planned to hold teachers' congresses in May 1907 in the cities of Russia and the All-Russian Congress of Muslim Teachers in August 1907 in Kazan for the earliest possible development of a unified program. Muslim educational institutions should be funded by the state and zemstvos, and schools should be supervised by an elected board;

- Reorganization of the management on the spiritual affairs of Muslims, namely: the Muslim clergy should be equal in rights with the Orthodox; the position of mufti should be made elective (for 5 years); all religious affairs should be transferred to the Spiritual Assembly (Mahkama-i-Islamiya) which should be free from state interference; establish the highest elective office of the Muslim cleric Raisul-Ulam in Russia, who should be given the right of personal reports to the emperor about the needs of Muslims (National Archives of the Republic of Tatarstan, Fund 186, Inventory 1, file 10).

Subsequent Muslim congresses and meetings took place in the context of the general political situation associated with the beginning of the work of the Russian parliament and the formation of a Muslim fraction. In January 1907, an attempt was made to hold the IV All-Russian Muslim Congress. However, permission to organize the congress was not received; the organizers were not even able to hold private meetings (This is due to changes in government policy towards the Muslims of the Volga region, 2005).

\section{Summary}

Thus, the All-Russian Muslim Congresses became a response to the objective requirements of the time, helped the Muslims of Russia to rally to consolidate efforts and create a new movement in the Russian political arena, namely, the Muslim Party of Russia.

Consideration of the issue on legalizing the Ittifak al-Muslimin party continued until 1917. Despite the moderation of its program and the clear intention of the leaders of the Muslim party to work under legal conditions, Ittifak al-Muslimin never became a political party. But in the preFebruary period, it remained the only political organization of Muslims that had an all-Russian character. The leaders of "Ittifak al-Muslimin" took part in the Duma elections; they created in the Duma the Muslim fraction, which operated in all convocations of the State Duma having turned into a kind of national political centre.

Despite the fact that Y. Akchura, G. Iskhaki, G. Barudi, H. and S. Maksudi, S.-G. Alkin, G.-R. Ibragimov, H. Yamashev, M. Sultan-Galiev were educatees in the same cultural environment, they disagreed on plans for the further development of Tatar society, as well as on a number of political issues.

Y. Akchura, S. Maksudi, and S.-G. Alkin were in parallel both members of the "constitutional democratic party" (Aynutdinova L.M. Liberal movement in the Kazan province (1900-1917), 2003), and proclaimed the principles of constitutional and parliamentary monarchy, democratic freedom, cultural self-determination of nationalities, compulsory alienation of landlord lands for ransom, the legislative solution of the "labour question" (Tatar Encyclopaedic Dictionary, 1999). Despite the commonality of party interests, disagreements arose between them. In particular, G. Iskhaki insisted on the recognition of the Ittifak-al-Muslimin organization as a cultural association, the purpose of which was to unite the efforts of the Muslim peoples of Russia in solving the problems of raising national self-awareness, developing culture and enlightenment. In general, G. Iskhaki by his political convictions was close to the Party of Socialist Revolutionaries (SRs) on the issues of recognizing the rights of non-Russian peoples. But by 1917 his political views were changing and the issues of state self-determination and the unity of the 
nation came to the fore (Mukhametdinov R.F. The origin and evolution of Turkism. - Kazan, 1996).

Yu. Akchura attached great importance to the formation of national capital and the bourgeois class. He believed that the development of capitalism was necessary to eliminate the plight of the employees, peasants and urban strata. In his opinion, the modern state should protect democracy, independence, national and economic freedoms of citizens. He was also a supporter of land reform, that is, the elimination of large landed estates. Yuri Akchura considered the nation to be the dominant force of the modern state. The main property of the nation state is democracy, which must rely on its own economy (Mukhametdinov R.F. The origin and evolution of Turkism. Kazan, 1996).

S. Maksudi and S.-G. Alkin stood for the cultural and national autonomy of the Tatars. These figures took part in the work of the Muslim fraction in all convocations of the State Duma. At the end of 1905 - beginning of 1906, the constitution of local branches of parties of the liberal direction took place in the Kazan province. The impetus for their formation was the events of the Revolution of 1905-1907, and the purpose of their activities was to reform the existing regime on the basis of a liberal program. The radical direction of the liberal movement in the Kazan province was represented by the "Constitutional Democratic Party", the core of which was the Kazan intelligentsia. The moderate direction of the liberal movement was represented by three organizations: the Kazan Party of the Manifesto on October 17, the Union of October 17, and Ittifak-al-muslimin. The Revolution of 1905-1907 allowed liberal leaders to go beyond the economic problems they had to deal with in local government and make political demands. The liberal movement entered the political arena and declared its readiness to fight for power within the framework of existing legislation with the aim of reforming it (Aynutdinova, 2003). The result of an unprecedented national upsurge in 1917 was the setting of the goal of achieving political sovereignty. This project was implemented after a number of stages in 1920 in the form of Soviet autonomy. Some researchers believe that the Bolsheviks created nations in Russia. However, the merit of the Bolsheviks lies objectively only in the fact that they went to create national republics. It was the demands of the most advanced nations that made them agree to federalize the country. The Tatar Autonomous Republic contributed to the formation of new modern forms of national culture, became the centre of the Tatar nation, since it was from here that integration impulses came.

\section{Conclusions}

Thus, the paradigm of national development established by the Jadidists continued to operate, exerting a tremendous impact on all aspects of the life of Tatar society. The goals set by the national movement at the beginning of the 20th century remained extremely relevant in subsequent years, and some of them were realized within the framework of the autonomy. Although the Soviet period in the history of the Tatar people is very ambiguous, it should be said that it was at this time when the material and technical basis of modern culture was established and a system of institutions was created aimed at its development and propaganda. First of all, this concerns scientific institutes. However, there were also negative tendencies, the main of which was the narrowly regional orientation of the cultural policy of Tatarstan.

\section{Acknowledgements}

The work is performed according to the Russian Government Program of Competitive Growth of Kazan Federal University.

\section{References}

(1913). Musulmanskaya gazeta, 10.

(1996). Mukhametdinov R.F. The origin and evolution of Turkism. - Kazan, - p. 118.

(1996). Mukhametdinov R.F. The origin and evolution of Turkism. - Kazan, - P.73.

(1999). Tatar Encyclopaedic Dictionary. - Kazan, - p. 288. 
(1999). Tatar Encyclopedic Dictionary. - Kazan,- P. 231.

(1999). Tatar Encyclopedic Dictionary. - Kazan,- P.556.

(2002). Tatar Encyclopaedia Vol.1. - Kazan, - P.642. The work of the III All-Russian Muslim Congress was covered in the works by: A.A. Litvin. Social and political movement in the Volga region. Late XIX-early XX century. Russian historiography. - Kazan, 2003.-P.199., Tsiunchuk R.A. Duma model of parliamentarism in the Russian Empire: ethnoconfessional and regional dimensions. - Kazan, 2004. - P. 205, Usmanova D.M. Muslim representatives in the Russian parliament (1906-1916). - Kazan, 2005. - p. 139.

(2002). Tatar Encyclopaedia Vol.1. - Kazan,- P.642.

(2005). This is due to changes in government policy towards the Muslims of the Volga region. Usmanova D.M. Muslim representatives in the Russian parliament (1906-1916). - Kazan, p. 141.

Aynutdinova, L.M. (2003). Liberal movement in the Kazan province (1900-1917). - Kazan, - p. 36.

Aynutdinova, L.M. (2003). Liberal movement in the Kazan province (1900-1917). - Kazan, - p. 52.

Aynutdinova, L.M. (2003). Liberal movement in the Kazan province (1900-1917). - Kazan,- p. 54.

Nafigov, R.I. (1964). Formation and development of advanced Tatar social and political thought (Essay on the history of 1895-1917). - Kazan,- p. 158.

National Archives of the Republic of Tatarstan, Fund 1370, Inventory 1, file 1.

National Archives of the Republic of Tatarstan, Fund 186, Inventory 1, file 10.

National Archives of the Republic of Tatarstan, Fund 186, Inventory 1, file 10.

National Archives of the Republic of Tatarstan, Fund 199, Inventory 1, file 906.

National Archives of the Republic of Tatarstan, Fund 420, Inventory 1. File 50.

Sternberg, G. (1910). Members of national minorities. General overview. Forms of the national movement in modern conditions. - SPb.

Tsiunchuk, R.A. (2004). Duma Model of Parliamentarism in the Russian Empire: EthnoConfessional and Regional Dimensions - Kazan. - P. 205.

Usmanova, D.M. (2005). Muslim representatives in the Russian parliament (1906-1916). - Kazan, - p. 129.

Usmanova, D.M. (2005). Muslim representatives in the Russian parliament (1906-1916). - Kazan, - p. 134.

Usmanova, D.M. (2005). Muslim representatives in the Russian parliament (1906-1916). - Kazan, - p. 135.

Usmanova, D.M. (2005). Muslim Representatives in the Russian Parliament (1906-1916). - Kazan, - P. 135.

Usmanova, D.M. (2005). Muslim representatives in the Russian parliament (1906-1916). - Kazan, - p. 136.

Validov, J. (1923). Essays on the history of education and literature of the Tatars. - M.; Pg. 